\title{
Does Multicultural Education Affect the Druze Heritage Curriculum?
}

\author{
Janan Farajh Falah \\ The Arab College for Education, Haifa, Israel \\ Email: Jananf81@gmail.com
}

How to cite this paper: Falah, J.F. (2018) Does Multicultural Education Affect the Druze Heritage Curriculum? Open Journal of Social Sciences, 6, 257-271. https://doi.org/10.4236/jss.2018.61019

Received: December 19, 2017

Accepted: January 27, 2018

Published: January 30, 2018

Copyright (C) 2018 by author and Scientific Research Publishing Inc. This work is licensed under the Creative Commons Attribution International License (CC BY 4.0).

http://creativecommons.org/licenses/by/4.0/

\begin{abstract}
Recent researches on the subject of education, the process of educational modifications, educational autonomy and school effectiveness, prove that the great importance of multicultural education in Israel, for the State of Israel is a mix of ethnic heterogeneity with varied national groups and religious beliefs and cultures, which take an active part in developing dialogue and mutual acceptance of the "other", assuming that there is no "monopoly" on the truth (Gladi, 2009) [1], namely, the State's majority does not control the minority's educational processes. The current research focuses on the unique legacy of the Druze. The aim of the research is to identify the teachers' attitudes towards the subject of the Druze heritage and multiculturalism in the Druze school system. The research question is how multiculturalism program embedded in the Druze education system. For this purpose, 5 teachers who teach the subject of Heritage were interviewed. The findings indicate that the subject of Heritage is a dual tool that enables implementing the curricula under certain circumstances. In the past, the subject was aimed to develop the new "Israeli Druze identity", while at the present, it is aimed to elaborate multiculturalism in school. In addition, at the period of globalization and the massive media, the subject of heritage is balance and braking method for Druze youngsters, in order to strengthen their relations to the Druze values and beliefs.
\end{abstract}

\section{Keywords}

Multicultural, Education, Druze, Heritage, Curriculum, Israel

\section{Introduction}

The State of Israel is a multicultural country, and the Druze Community is part of its "human mosaic". The status of the community is unique, on the one hand 
its origin is part of the Arab minority, on the other hand, the Druze serve in the IDF and take an active part in the State's life, thus, the army service enable them to integrate in the Israeli-Jewish society.

The Multiculturalism discipline embraces multiplicity of cultures and cultural differences, cultivating mutual respect, equality and balance between the varied groups and cultures. In this manner, the uniqueness of each group is stored, and at the same time, interacts and affects each other.

Today, education towards multiculturalism has greatly increased, for the world has become more dynamic and greatly modifies, as a result, multiculturalism enables to enhance a person's capacity and uniqueness towards cooperation, assuming that common traits would overcome differences and lead eventually to greater results. In addition, multiculturalism enables people to become self-fulfilled while maximum contributing to one's environment. Thus, people live by the order of the day and adjust themselves by its conditions. The Druze community in Israel is a good example; its common interest with the Jewish community is the State's defense and secure, this is the reason why they serve in the Israeli Army.

The aim of the study is to locate the teachers' attitude towards the subject of multiculturalism in the Druze Education System. The research question is how multicultural programs embedded in the Druze education.

\section{Review}

\section{What Is Multiculturalism?}

Before we examine the issue of multiculturalism, we are required to understand the concept of culture and its meaning. (Shemer, 2009) [2] describes culture in its common fundamental definition, a group of people who share common aspects of values, traditions, norms, behavior and mentality. Usually, people tend to attribute the term to ethnic traditional aspect resulting in people's origin. Furthermore, culture should be related to varied different groups by age, nationality, gender, religion, etc. People of these groups share common characteristics, which are solely unique to their group.

(Taylor, 1994) [3] argues that, a person needs to have an identity and mutual recognition. He examines historically the period before the French Revolution and claims that society was made of social classes, the European person (or nor European) was born into a certain status and usually remains in this class until one's death. In this situation, a person accepted one's status, wither one is superior or inferior to the other, an element which had contribute to one's sense of secure and stability. The French Revolution, and the Industrial Revolution, had led to changes in social mobility that mainly nurtured and undermined one's self-confidence, for if had become possible to climb the social ladder, yet it also meant that one could be dragged down very quickly.

Gretz (1960, in: (Sharon, 2004) [4]) indicates that multiplicity of definitions only construct ambiguity. Out of all proposed explanations, the research sug- 
gests four prominent definitions (Gretz, 1960, p. 16, in: (Sharon, 2004) [4]):

1) Culture is social heritage that the individual attributes to one's group.

2) Culture is a theory of anthropologist aimed to examine the manner a group of people actually behave.

3) Culture is a mechanism for determining normative standards of behavior.

4) Culture is a frame of mind, thoughts and beliefs.

Another typical definition of Israel is "Culture could be a form of religion, or of country of origin. Yet, music is culture too... painting and movies are certainly part of culture. A Hebrew accent is a cultural marker, also places of residence such as Beth Shean or small Settlements in the Galil, living in Bnei-Brak, these have also received a cultural distinction, in other words, culture refers all" (Calderon, 2000, p. 142) [5]. In the Israeli context, it is evident that the State of Israel is a State of immigration, in addition to its Arab residents; the arrival of groups of Jews from different countries soon became the dominant group in the country. Thus, the different "Aliya" (Jewish immigration) at the early 20th century had made Israel heterogeneous with diverse ethnic groups, varied nationalities which are categorized by religious belief, etc. (Gladi, 2009) [1]. The uniqueness of the State of Israel is in its varied ethnic groups, each dominant group contains of varied sub-groups which differ one from each other, this is the reason for being a "cultural mosaic".

Sharon (2004) [4] claims that the main characteristics of multicultural society is diversity of groups, that is to say, multiple and different lifestyles, some are familiar and some are non, creating dialectical tension between each other in order to become similar and to face the variance. Moreover, these tensions between the groups could lead to confusion, disruption and insecure, which are emphasized by withdrawal, resistance or seclusion. Opposite reaction is openness and acceptance. The term multiculturalism has three aspects: ideological, structural and demographic. In Israeli context one might argue that Israel is clearly a multicultural State, due to its cultural diversity (Sever, 2001) [6]. As for the second aspect of ideology, by Sever's definition (2001) [6], it is required first to observe society's attitude towards the existence of cultural diversity and the manner of coping with it. The third aspect of structure requires examining the division of power and resources between the various cultural groups (Sever, 2001) [6]. In light of this definition, there are six models for managing multiculturalism and diversity in different societies (Sever, 2001) [6]:

1) The model of Segregation-when one group considers itself better or superior and acts in accordance, by creating physical and racial segregation to preserve its superiority.

2) The model of Assimilation-known also as the "Melting Pot". This requires all immigrant-cultures to renounce their origin and assimilate the new dominant group.

3) Transitory Pluralism - a model which apparently provides tolerance towards other cultures, for it does not require immediate assimilation and does 
accept the differences, yet, expects complete assimilation at later phases.

4) The Residual Multiculturalism Model-recognizes the legitimacy of unique cultural elements, especially ethnic or folkloristic (events, food, etc.), yet, it demands assimilation to the dominant culture and renunciation of cultural key elements of the country of origin such as language, educational conceptions, etc.

5) Federative Pluralism provides equal social and cultural status to all groups, with no intention to maintain interaction or assimilation at all.

6) Interactive Multiculturalism strives to maintain inter-cultural relations, for it recognizes the importance and contribution of mutual reference in creating of wide common life for all ethnic groups (ibid.).

The six models can be classified into two main categories of "isolating models" which characterized by hierarchy and asymmetry as in models 1 to 4 , and "integrating models", which are characterized by equality and symmetry between cultures and groups associated as in models 5 and 6 (Sever, 2001).

\section{The Druze Education System}

This section presents the common attitudes of the period of the establishment of Israel (1948), until the Ministry of Education had excluded the Druze out of the Arab culture and education department, and established "The Education \& Culture Committee for Druze".

Al-Qasim (1976) [7] argues that the Israeli victory in 1948 had contributed greatly to the formation of pro-Israeli leadership and the beginning of 'Blood Pact' with the Jewish community. In 1956, the State of Israel declared the Druze as a distinct ethnic community and contained Conscription on its men (Faraj Falah, 2005) [8].

After applying the Law of Compulsory Service, and the decision to alter the nationality in the ID card from "Arab" to "Druze", Druze students had begun to resist the policy with the leadership of the "Young Druze Committee". After the Six-Day War (1967), with the active participation of the Druze men in the war, the Palestinians referred the Druze as traitors, an accusation which only strengthened the anti-Arabic policy within the Druze community. After the war, the separation between the Druze community and the Arab one, and becoming part of the Israeli State, the process was irreversible and became fait accompli. Yet, in 1972 an Initiative Druze Committee against Government policy towards Druze was founded, one of its major principles was to repeal Conscription, ending expropriation of Druze lands and the intervention in the internal affairs of the community. The last straw for the intricate relationship between the Druze and the Establishment were the events of April 1974, in which, Druze and Druze spiritual leaders were humiliated by Jews in Kiryat-Shmona, Tiberias and Eilat on the background of the murder in Kiryat Shmona by Palestinians (Al-Qasim, 1976) [7]. The friction and the deterioration of relations between Druze and Jews (even though it of low percentages) had greatly worried the Government. As a result, the Government established two committees (Ben Dor Committee \& 
Shekhterman Committee) to examine the events and to restore the "blood pact" once again. Thus, the raising of ethnic consciousness was needed. In order to realize this goal, the Druze education was separated from the Arab one and special curriculum were designed (Al-Qasim, 1976) [7].

The second position supports the perception of the Druze from the late 1940s that chose ethnic particularism with the encouragement of the new State (Oppenheimer, 1978) [9]; (Falah, 2000) [10]. This policy was accomplished by the Conscription of the Druze men to IDF since 1956. Furthermore, in 1957 the Druze in Israel were recognized as a religious community, and in 1963 the Government had granted the Druze legal religiously independent status by the Sharia, basing on centuries old tradition, in which the Druze used the Muslim Sharia Law (Falah, 2000) [10]. Hence, in addition to this modification, the school curricula were also replaced in order to strengthen the Druze identity and communal particularism. The academic program was aimed to reassure the Druze concern from assimilation and dissociation of its younger generation from tradition and religion. Consequently, the demand for ethnic consciousness had increased. To gain this purpose, it was required to separate the Druze education from the Arab one, and to create special educational programs (Falah, 2000) [11].

The Ministry of Education \& Culture separated the Druze education from the Arab Department of Education, and established "The Druze Culture \& Education Committee" to develop and supervise the special pedagogic contents (Faraj Falah, 2005) [8]. The Chairman of the Committee was Dr. Salman Falah (R.I.P), a nominee of the entire Druze education in Israel. In its early stage, the Committee's efforts were focused on designing the school curricula. In 1976, it was decided to include Heritage Studies. Two institutes opposed this decision (Fara Falah, 2013):

$\square$ The Druze spiritual leaders who feared from revealing their secret religion, which is sealed also from non-religious Druze.

The Druze Initiative Committee, with the assistance of radical elements, that argued that the Druze heritage is part of the Arab Palestinian heritage, hence, highlighting of the Druze unique heritage would apart them from the Arab national heritage and would create a Druze independent one.

The curriculum of the Druze heritage included cultural and unique principles, and religious and historical figures. The books were made for Druze children from the third to the twelfth grade. The students of the twelfth grade were required to be tested in the subject ( 2 units) as part of the Matriculation examination demands, one unit was compulsory and one was elective (Faraj Falah, 2013) [12].

The Druze educational system has passed many forms. After the establishment of the Israeli State, it was part of the whole Arab educational system. In 1975 it was separated and became independent for 17 years, until 1992, when the era of Druze Educational Committee was ended, and the Committee's role was returned to its original size. Nevertheless, it did not change reality (Falah, 2000) 
[10].

Between the years of 1991 to 1995, a new era of integration has begun, in which, the Druze schools were spread in the region and the sector was equally supported as the Jewish sector by means and pedagogic hours. From 1995 to 2000, the Druze education was strengthen and improved tremendously in order to develop communal leadership, up-dated teaching methods, to encourage learning of Science and Technology, to meet the needs of special education students, to extend public libraries, to implement long school day, to encourage educational initiatives and to emphasize unique Druze programs. Afterwards, there came Dovrat Committee etc.

The first time that education programs for the Arab and Druze minority were proved were in 1972, three years later, new goals were developed by the team of "The Arab Education Planning for the 80s", headed by Dr. Matti Peled' the CEO of The Ministry of Education. The goals were approved by the Ministry in March 1975 (Faraj Falah, 2013) [12].

The aims of the Israeli Druze Education system were formed in 1975 (Tzarzur, 1981) [13], "To generate the educational values of the Druze's Arab culture in science, peace between Israel and its neighbors, to share love between all citizens of the State, to create active partnership and participation in Israels defense while emphasizing the special interests of all residents, and on nurturing the special relations between Jews and Druze by learning the Jewish culture, and by cultivating the Druze Israeli identity and heritage among the Druze youngsters and the sharing of faith between the Community in all countries of resident'.

The manner the targets were conveyed emphasizes the Druze Arab nationality, yet they were defined as a Community and not as a nation. A profound perspective on the purpose of the Druze education proves that the authors also had recognized their Arab nationality as a Community not as a nation. In addition, it was mentioned that the Druze education should be based on the Arab culture as well, probably assuming that the culture of the Druze student is Arab. The Druze educational goals are similar to those of the Arab ones, except for the issue of "the nurture of special bonds between Jews and Druze, the nurture of the Druze identity and heritage among the young Druze, and the common faith between Druze Community in all places of residence". This means that the State refers to the Druze as an ethnic group, beyond its boundaries, in order to highlight their uniqueness from the rest of the Arab world, thus, although the Druze are Arabs, the emphasis is on their Druze identity and their bond with the Druze worldwide and relations with the Jews in Israel, in the process of ignoring their relation to the Arab nations which they belong to (Tzarzur, 1981) [13].

\section{The Druze Heritage at the Beginning}

The Committee needed foremost to prepare new curriculum for the Druze schools by the name of heritage (Faraj Falah 2005) [8]. The Committee had decided that the Druze Heritage Studies would be learned in grades second to 
twelfth for 2 hours per week, and would be considered a mandatory subject in the Bagrut. The program was designed as a base to begin with, and in the course of studying books would be written for each grade. The contents were divided into two parts: The first part included all aspect of the Druze Community, such as holiday, customs, manners, etc.; The second part was focused on the relation between the Druze and Jews and the State of Israel and included stories about decorated Druze soldiers, Druze soldiers who were died in battle, conscription, and Druze-Jews relation in the period of the British Mandate. Beyond that, it was decided that only Druze teachers would teach the subject. In addition, it was decided that students in elementary school would learn the profession in the KHilwa (Druze Chapel) under the title of Druze Heritage. Eventually, the subject of "Druze Heritage" had entered the curricula on September 1, 1977, two hours per week (Tzarzur, 1981) [13] (Farraj Falah 2006) [14].

Since 1993, ten books were approved, six of them for elementary schools and four for the middle schools and high schools. It is important to emphasize that all of these books foster the Druze Israeli identity, and thus, in practice, the Druze heritage has become means of inheriting of the Druze-Israeli identity with the State's approval, in contrast to Druze who were against it, as it is emphasized in the research of Aden \& others (1985) [15].

\section{A New Druze Heritage Curriculum}

The new curriculum is based on accumulated teaching experience of 25 years of the Druze heritage (Faraj Falah 2016) [16]. The new plan needed to address up-dated educational approaches in addition to pedagogic ideology of the Druze heritage. This was emphasized by a desire to preserve the cultural heritage, the values and the uniqueness of the Druze community, and on the other hand, the need to meet the changes the Druze society has experienced over the past two decades, due to processes of secularization and modernization that characterize the western world in general, as part of the globalization, a world in which students are continuously exposed to the Media, contents and messages whether it is by newspaper, TV, the Internet and Web, in addition to cultivation of the Druze identity and loyalty to the State of Israel and to democracy (Ministry of Education, 2013) [15].

According to the Ministry of Education (2013) [15], the aim of the new curriculum is "to develop conscious and deep affinity to the Druze identity, heritage and Arabic language, as part of its culture and identity. Students will absorb the norms, behavior and values of the Druze religion, which are the solid foundation of Druze heritage, and at the same time, will be able to balance between these norms and the western modern ones of the State of Israel. Students would be able to enhance their civic awareness towards the State of Israel, to be fully participants in the State's life, to contribute and construct amoral, ethical society with a commitment to coexistence between all citizens of the State." 
Following the program's goals:

1) To understand the social and spiritual values of the Druze community, to follow its values on daily life and to strengthen community ties.

2) To accept The Druze folk heritage as part of the Eastern Arabic heritage and its importance for the Community.

3) To distinguish between two main elements of the folk heritage: the cultural -social spiritual one (of folk poetry, literature, music and dancing) and the material one (of the buildings, holy sites, crafts, furniture and decorations).

4) To embrace universal humanistic values as part of the Druze Community as the basis for sharing of live within the State of Israel, values of respect of different opinions and beliefs regardless one's origin, race, religion and gender.

5) To accept Druze women status by the Druze religious ethics and the responsibility of the State and society to preserve their rights.

6) To understand that peace is a binding universal value that eliminates any expression of violence and hurt in cases of disagreement or conflicts between people.

7) To be able to integrate within the constantly changing modern world while maintaining the values and culture of the Druze Community.

8) To understand the relationship between the Druze heritage and culture to the Arab Middle East history.

9) To recognize the history of the Druze Community in order to create sharing of faith among its people.

10) To understand the importance of cultivating good relations with different population groups, to act and nurture these relations.

11) To nurture the relations with Druze worldwide communities, to be involved in the local social life of the Community.

\section{The changes in the new curriculum in relation to the former one:}

1) Some of the topics were expanded and two new ones were added: the monotheistic philosophic aspects of the tradition and the development of the Druze heritage.

2) The program is intended to be a tool for teachers' efforts to develop and assess processes, hence, unlike the former program, the contents designed all ages and followed by examples of proper educational activities and specifications for each studied subject, in addition to its general goals.

3) The latest plan is more extensive, both in terms of contents and pedagogic conceptions.

4) The program has been expanded for all ages between the ages of 6 years old to 18 years old. Furthermore, it expands the units of the Matriculation Exam to 5 units instead of the 2 mandatory units of.

\section{Methodology}

\subsection{The Research Method}

The current study is about the unique subject of the Druze heritage. The aim of 
the research is to locate teachers' attitudes towards multiculturalism in the Druze education system. The research question is how these multicultural curricula are embedded in the Druze education. Hence, the research method is qualitative, an approach which enables a study of human subjective experience without measuring the experience itself (Shkedi, 2011) [17]. The qualitative method is based on the interviewees' subjective interpretation within their society, rather than studying their history (Zabar Ben-Yehoshua, 2001) [18].

\subsection{The Study Objects}

The research includes interviewing of 5 teachers who teach the subject of Heritage. Below is Table 1 of the interviewees' demographic data (the names are fake).

\subsection{Research Tools}

The common qualitative paradigm includes a varied use of research tools (interview, focus group, observation, observation, brainstorming, etc.). The researcher selects the tools in accordance to the research questions and issues (Shkedi, 2011) [17], in this case, interviewing was chosen as the most suiting method tool.

The interview is Semi-structured, a method of data collection which demand the researcher's involvement. The goals of the interview are diverse, aiming to get the interviewee to change one's attitude towards the issue, a person or to the change itself, to transmit a new information, and to assist the interviewee to gain an insight regarding particular social incident, etc. (Zabar Ben-Yehoshua, 2001). The selected semi-structured interview is the most appropriate tool for a semi experience array; this is the reason that it is less common in a qualitative research. The interview usually is made in advance; pre-styled questions or outlines are written to serve the research question and goals, though, the questions and their order are not pre-determined (ZabarBen-Yehoshua, 2001) [18].

\subsection{The Research Process}

I had a prior acquaintance with the study participants; I applied them to participate in the study, explaining the research purpose. After receiving their consent, we set the time and place to make the interview; they all preferred to conduct the interview in their home.

Table 1. The interviewees' demographic data.

\begin{tabular}{ccccc}
\hline No. & $\begin{array}{c}\text { The name } \\
\text { (fake one) }\end{array}$ & Age & Class & $\begin{array}{c}\text { Experience in teaching } \\
\text { the profession }\end{array}$ \\
\hline 1 & Nhad & 55 & $10^{\text {th }}$ to $12^{\text {th }}$ grade & 25 \\
2 & Athman & 49 & $10^{\text {th }}$ to $1^{\text {th }}$ grade & 21 \\
3 & Ghada & 38 & $8^{\text {th }}$ to $9^{\text {th }}$ grade & 14. \\
4 & Magda & 46 & $10^{\text {th }}$ to $12^{\text {th }}$ grade & 22 \\
5 & Huda & 28. & $5^{\text {th }}$ to $6^{\text {th }}$ grade & 4 \\
\hline
\end{tabular}




\section{Findings}

The findings are based on five teachers' interviews, teachers who teach the subject in middle school and high school.

The interviews raise several issues, such as, the differences between teaching the subject in its former draft and in its new one. Another issue is educating towards multiculturalism in Druze schools. The participants refer to several issues, for example, what is multiculturalism and whether it exists in the State of Israel, how does it emphasized in the curriculum, and how to measure success of the program.

The data were reduced into some categories by subject, and were coded, in order to simplify the process. At the end of the process, the interviews were clearly divided into three themes, each theme included the following categories:

1) The uniqueness of the subject of Heritage-consists of two categories: the old program and the new one, and the uniqueness of the subject.

2) Multiculturalism-includes three categories: multiculturalism in the Druze curriculum, its relation to the subject of Heritage, and multiculturalism in daily life.

\subsection{The Uniqueness of the Subject of Heritage}

1) The former heritage curriculum-There is a consensus among the teachers-participants that the old curriculum is irrelevant to the 21 st century, for it mainly focuses on reinforcing the Druze identity apart from the Arab one, and in relation to the "Blood Alliance" with the Jews. For example, Nahad describes "The old program was designed in advance to support Government's policy, which its main concern was to supports the Druze distinction from the Arab one and to strengthen the relations with the Jews". He adds "The existence of such program was in itself important, for this field was not existed before, thus, it is important that our Youngers would recognize the Druze religious as much as our religion allows". Athman describes that "In the past, subjects in the favorite of the Governments were taught... this was proven to gain stability between the different communities and the State." Furthermore "It was necessary to create it properly... The Community was divided between being part of the Arab minority, and the great numbers of Youngers joining the IDF for economic reasons of being poor..." He also emphasizes that "It was necessary to build the Israeli-Druze identity in order to maintain the Druze identity, for the younger generation already begun to adjust to the Jew Israeli society and the State's institutes, adopting the western culture far from their own heritage. Thus, the build of a 'hybrids' identity of Arab-Israeli ones was necessary to the Druze development of identity". Ghada says "Back in the 1970s, the authorities allowed the Druze who had connections with the Government to build a new identity, as long as they would remain loyal to the State and Government. Thus, the heritage subject in its former structure was immediate and appropriate under the circumstances". Magda explains that "The Heritage topic came to replace the Muslim and Druze curri- 
cula from the 1950s... This alternative had come to strengthen the relations with the Jewish community and State". Huda claims that the contents she had studied in school were "Biased in favor of the Government and were aimed mainly to empower the Druze identity among the younger generation".

2) The new curriculum. Teachers agree that the new program meets the youth needs in the 21 st century. The innovative program allows various methods of teaching and implementation. Some of the interviewees assume that the modifications would be better for students and would expose them to new reality and essential issues. For example, Athman claims that “... The new heritage curriculum is better and great. It meets the needs of our time", furthermore, "The renewed contents and the new ones enable to teach the subject in a flexible manner". He adds "The new program is continuous of the former one, yet it is renovated and therefore, includes more subjects which intensify the Druze identity". Magda believes that "The new program is more beneficial and adjusted to the 21 st century, it enables acceptance of the 'other' and other religions... It refers to the changing environment while maintaining the values of the community". Huda, as the other interviewees, claims that "The new plan allows us-the teachers to learn and apply various teaching methods, $\mathrm{n}$ addition, to shape the youngers' perception toward their environment and the individual, accepting of the 'other' in the course of maintaining their Druze identity, as it was designed in the old program".

3) The uniqueness of the heritage study program: The interviewees agree that this field was a necessity at the beginning of the independent Druze education in the 70s as it is today, furthermore, the interviewees agree that the Druze identity is already embedded well after approximately 70 years, an element which requires less focusing on the identity and more on the issue of multiculturalism and tolerance towards the 'other', as Nahad describes “... In the 1970s, it was necessary to develop a curriculum that highlights the differences between the Druze and the Arabs and to emphasize the connection between the Druze and the Jews. I believe that today, this is less needed, for the Israeli Druze identity is already solid. On the other hand, globalization, secularization and western values contradict the Druze values, an element which raises the need to maintain the program". Athman says that the "Heritage field of study is essential and unique, constituting the Druze child's personality. In the past, it was needed to develop the Israeli-Druze identity, while today, I believe that it is designed to strengthen the identity, in order to balance between the unique values of the Druze community and the secular universal values of western society". Ghada believes that "It is very important to continue teaching this subject for the Druze religion forbids teaching religion in school, thus, heritage replaces religious lessons. I think that the new program balances between acceptance of the 'other' and the maintenance of the Druze tradition; this is the subject's uniqueness". Magda believes that "I support teaching the subject, for it is irreplaceable, it enables conveying many issues that would prepare Druze children to the 21st 
century". Huda claims that "Heritage studies are unique by contents and it assists conveying social vision and $s$ new updated concepts adjusted to our period".

\subsection{Multiculturalism}

1) Multiculturalism in Druze school curriculum and its relation to the context of Druze heritage: The interviewees' answers prove of the teachers' consensus regarding the importance of teaching towards multiculturalism. Furthermore, the participants claim that multicultural education is relatively poor in Druze schools; yet, it exists mostly in lessons of History, Heritage and encounters with other schools. For example, Athman describes that "It's hard to recognize topics of multiculturalism, the focus is on the Druze identity subject, yet, some of the subjects such as heritage, citizenship etc. relate to multiculturalism". Nahad specifies that "Multicultural education do exist, yet it is limited to encounters with other schools of other communities or religious groups, by school trips, or in the course of discussion at certain lessons". Ghada notes that "... Multicultural education is most evident in higher grades and less in elementary school by terms of extent and emphasis. It is very important that multicultural education would be part of school curriculum and culture; I'm making great efforts to implement the subject in the lessons of heritage at the eighth and the ninth grades". Huda describes "The curriculum is affected by society, and if society's nature is multicultural, the curriculum would include extensive cultural issues. Obviously, it is important that the new program includes multicultural elements, and would be wise to expand it in the future". Magda also strengthens this claim by saying that "The effect is well understood and well known. Elementary school already embeds these issues, if the State would decide to educate towards multiculturalism, then these values and elements would be nurtured already in early age". She adds "It's hard to find these programs in high schools. In my case, I do not implement multicultural, still, I try from time to time to explain and illustrate the meaning and variety of cultures whether by encounters with other schools or within heritage lessons".

2) Multiculturalism in daily life: Basically, multicultural education is appears to affect everyday life of the Druze both in young age and adult. The research participants argue that daily life is the key for multicultural education, it is emphasized by watching Hebrew TV shows, acting by Western codes and more. This also indicates of the importance of heritage subject for balance and control of different situations. For example, Nahad notes that "Reality determines and in the period of globalization and Media, individuals are exposed to other cultures and information... Every child has a mobile phone or computer to work with and get the necessary information. I assign great importance to this study subject, for it blocks and balance the uncontrolled tendency towards universal values... and enables polarity". Athman notes that "Progress made secularization and universal values exposed for everybody, it is important to know the 
'other', on the other hand, a person should not forget one's identity and values. I believe that the program in its new version, prepares the student to examine multiculturalism critically and intelligently". Magda describes that "I am aware that the young generation is greatly familiar with other cultures; it is illustrated by their actions and behavior... It is very important to expose them to other cultures, yet, as a special Community, we must not forget who we are... I try in my lessons (of heritage) to include as much as possible issues of multiculturalism and at the same time to emphasize our uniqueness as a Community". Gada states that "Multiculturalism cannot be ignored, it is not merely an issue of teaching of the subject, it is part of our daily life-TV shows, radio or the web (Internet). I see in the lessons of heritage a way to explain multiculturalism intelligently and in controlled manner".

\section{A Summary}

The aim of the study is to examine teachers' perception of the subjects of heritage and multiculturalism in the Druze school education. The research question is how multicultural programs are embedded in the Druze education.

According to the interviewees, two themes are raised, each theme has five categories. These are the main findings:

The first theme is the distinctiveness of the subject of heritage. There is consensus among the interviewees that the former program is irrelevant to the 21st century's reality. According to them, the former program is aimed to strengthen the Druze identity apart from the Arab in the course of emphasizing the "blood alliance" between the Druze and the Jews. Eden and others (1985), Tzarzur (1981) [13] argued that the purpose of this study subject is to reconstruct a new identity for the Druze apart from the Arab one and strengthening the relations with the State and the Jewish community.

The second category is the new version of Heritage Studies; the teachers-interviewees agree that it meets the needs of the young generation in the 21st century. The innovative program enables implementation of various teaching methods. Some of the interviewees still disapprove of the contents, for they feel that they are biased in favor of the Government, a tendency which should be stopped. The objectives of the new program are to create a continuity of the old one's targets with the addition of two aspect of Druze philosophy and the development of the Druze community. In addition, the program has been expanded and destined to all ages from the first and second grade to higher grades in high school. It also allows intensive study as it has become an elective course of 5 units' matriculation exam, instead of 2 units' compulsory subject. Furthermore, the program is updated, both in terms of contents and pedagogical concepts (Ministry of Education, 2013) [15].

The third category approves that the program is necessary at the beginning of the Druze education system in the 1970s and is still needed today. These days, the program should undergo some changes, in terms less focusing on a con- 
struction of the Druze identity and more on multiculturalism and knowing of the "others". This finding supports the hypothesis that the heritage subject has dual uniqueness in both periods is correct, in the first period it serves to construct the new "Druze Israeli identity", and fifty years later, to learn multiculturalism and the acceptance of "others" and less about the identity.

The second theme of multiculturalism, it is found that education towards multiculturalism is important, yet, not embedded in the Druze schools appropriately. Today, the heritage lessons in the new form, contain multicultural education especially in junior high and high school. Furthermore, it is evidence that multicultural education affects the everyday life of the Druze children and also their adult life. The interviewees argue that daily life is the key to multicultural education as it is reflected in TV shows in the Hebrew language. Hence, the importance of the Subject of Heritage is for it maintains balance and braking.

This finding illustrates reality, the curriculum in Druze schools are not supportive of multicultural education, and that the heritage subject is the main platform for implementing multiculturalism. On the other hand, the virtual activity and the use of the Internet also poses a platform for children and teenagers' studies, gaining of knowledge and information, preserving of social relationships, building of new ones, etc. This platform summons inter-cultural encounters and exposes the user's norms which do not necessarily meet one's culture and reality It is important to have barriers to delay virtual multiculturalism, for the damages are great and irreversible sometimes (Merkle \& Richardson, 2004) [19]. Thus, the new program of heritage is kind of regulation that balance and control the impact of multiculturalism on the young Druze, a major platform to teach heritage and values of the Druze community.

To sum up, it is apparent that the Subject of Heritage is a dual tool that enables implementation of the curriculum appropriately under all circumstances. In the past, it was necessary to construct the new Israeli Druze identity, today it is necessary to highlight multiculturalism. In addition, in the present age of globalization and massive media, the Heritage study-Subject is a system of balance and braking for Druze youngsters, to tie and maintain their relations with the Druze values and tradition.

It is recommended to conduct further research with greater number of interviewees to support these findings.

\section{References}

[1] Gladi, B. (2009) Multicultural Education in Israel-A Reality or a Vision? Et-Hasade (3), Ashleem, Jerusalem.

[2] Shemer, A. (2009) Professional Challenges in Working with Children from Multi-Cultures. Et-Hasadeh (3), Ashleem Publisher, Jerusalem.

[3] Taylor (1994) The Politics of Recognition. In: Guttman, A., Ed., Multiculturalism, Princeton University, New Jersey, 25-73.

[4] Sharon, H. (2004) Multiculturalism \& Education in 2000s: Updated Review, In: The Maintainance of Multicultural Society, The Arab College for Education, UNESCO 
Israeli Committee, Book of the Conference, Haifa, 23-67.

[5] Calderon, N. (2000) Pluralistic by Force: Multiculturalism in Israel. Haifa University Publications, Zmora-Bitan, Haifa.

[6] Sever, Y. (2001) Boil or Weave? Conceptions to Examine in Multiculturalism Issues. In: Gadish Education for Adults, 45-54.

[7] Al-Qasim, N. (1976) The Druze in Israel. Nazareth (Arabic Language).

[8] Falah, J.F. (2005) The Druze Woman. Barkai Publications, Rishon-Leziyon.

[9] Oppenheimer, J. (1978) The Druze in Israel as Arabs and Non-Arabs: An Essay on Manipulation of Categories of Identity in Non-Civil States. Cambridge Anthropology, 4, 23-44.

[10] Falah, S. (2000) The Druze in the Middle East. The Ministry of Defence, Jerusalem.

[11] Falah, S. (2000) Fifty Years to the Education System in Israel. The Ministry of Education, Jerusalem, Chapter 6, 112-139.

[12] Falah, J.F. (2013) The Portrayal of Women in Israeli Arabic 12 Textbooks on Druse Heritage Us-China. Education Review, 3, 33-37.

[13] Tzarzur, S. (1981) Arabic Education in the Jewish State: Major Issues. In: General Har, The Ministry of Education, Jerusalem, 113-131.

[14] Falah, J.F. (2006) Attitudes of Druze Youth in Israel toward Druze Women. In: Fialkoff, M. and Kirmayer, P., Eds., Adult Education in Israel, Vol. 9, 182-188.

[15] Aden, S., Wolf, Y. and Azam, F. (1985) The Druze Heritage in Schools. Values, Targets \& Trends, 26, 295-306. The Ministry of Education Publisher, Jerusalem.

[16] Falah, J.F. (2016) The Status of Druze Women in the Druze Religious Law in Comparison to Druze Women's Status in Society. International Journal of Multidisciplinary Research and Development, 3, 203-206.

[17] The Ministry of Education (2013) The Druze Heritage in the Curriculum of the First \& Second Druze Grades. The Department of Heritage, Jerusalem.

[18] Shkedi, A. (2011) The Meaning beyond Words: Methodologies in Qualitative Research-Theories \& In Practice. Ramot Publications, TLV.

[19] Zabar Ben-Yehushua, N. (2001) Trends \& Traditions in Qualitative Education. Dveer Publisher, Tel Aviv. 